\title{
Molecular Characterization, Hematological and Biochemical Studies on Foot and Mouth Disease Virus Serotype $O$ in Buffaloes and Cows in Dakahlia Governorate, Egypt
}

\author{
Shefaa A.M. El-Mandrawy ${ }^{1 *}$ and Gamelat K. Farag ${ }^{2}$ \\ ${ }^{1}$ Clinical Pathology Department, Faculty of Veterinary Medicine, Zagazig University, 44511, \\ Egypt \\ ${ }^{2}$ Virology Department, Faculty of Veterinary Medicine, Zagazig University, 44511, Egypt \\ Article History: Received: 27/4/2017 Received in revised form: 21/5/2017 Accepted: 12/6/2017
}

\begin{abstract}
The present study aimed to evaluate the hematological and serum biochemical parameters in buffaloes and cows infected with foot and mouth disease (FMD) virus. Forty buffaloes and cows (6 months - 2 years old) were used. Twenty buffaloes and cows clinically healthy and were used as control, the other twenty buffaloes and cows showed characteristic clinical signs of FMD. Blood samples were collected and serum was separated from both groups to measure the hematological and biochemical parameters. Infected buffaloes and cows showed fever, anroxia, excessive foamy salivation and ulcer formation in the mouth. Compared to the control buffaloes, erythrocytic count (RBCs), hemoglobin $(\mathrm{Hb})$ and packed cell volume (PCV) in the FMD infected buffaloes were significantly decreased, while mean corpascular hemoglobin $(\mathrm{MCH})$ was significantly increased. In addition, significant increase in toltal leukocyte count (TLC), neutrophils, with a significant decrease in eosinophil and lymphocyte counts were observed. Moreover, cows infected with FMD virus showed no significant changes in the erythrogram, while, significant increases in TLC and neutrophils, with a significant decrease in eosinophil and lymphocyte counts were observed when compared with the control group. There were significant decreases in the levels of serum total proteins, albumin and globulin, while serum asprtate transferase (AST), creatinine phospho-kinase (CPK), glucose and cortisol levels were significantly increased in the infected animals. Tissue and saliva specimens were collected and analyzed by using universal primer using reverse-transcription polymerase chain reaction (RTPCR). All the identified viruses were of serotype ' $O$ '. It is concluded that FMDV serotype ' $O$ ' is circulating among cows and buffaloes in the study area.
\end{abstract}

Keywords: FMD, RT-PCR, Cows, Buffaloes, Cortisol.

\section{Introduction}

Improving cattle and buffaloes' production in Egypt is a recognized pathway to alleviate rural poverty and improve food security. Foot and mouth disease (FMD) is a highly contagious and fatal viral disease of bi-cloven animals. The disease leads also to economic losses which include reduction in milk and meat production, reproductive inefficiencies and death in young ruminants [1]. It is characterized clinically by fever, depression, anorexi and, excessive foamy salivation with vesicles appearing on the tongue [2]. Some infected animals remain asymptomatic, but they dissiminate the virus to other animals. Initial diagnosis is usually done on the basis of clinical signs, while, confirmation of the the etiological agent is based on Reverse transcriptase-polymerase chain reaction (RT-
PCR) which is reliable, rapid and highly sensitive method for early diagnosis [3]. The FMDV belongs to the genus Aphthovirus of the family Picornaviridae. There are seven serotypes (O, A, C, Asia1, SAT1, SAT2 and SAT3) and more than 65 subtypes [4]. Mixed rearing of cattle, buffaloes, sheep and goats has lead to the persistence infection and spread of FMDV [5]. The virus is RNA virus which is non-enveloped, positive sense ssRNA genome of about $8.3 \mathrm{~kb}$ and enclosed within a protein capsid. This protein capsid is composed of 60 copies of four different structural poly peptides (VP1, VP2, VP3) which are surface, while, VP4 is entirely internal [6-8]. The VP1 protein is highly immunogenic, whereas, VP2 and VP3 contribute to the antigenic properties of the virus [9].

*Corresponding author email: (shifo_vet@yahoo.com), Clinical Pathology Department, Faculty of 156 Veterinary Medicine, Zagazig University, 44511, Egypt. 
The purpose of this study was the molecular detection of FMDV in clinical samples obtained from suspected animals using RTPCR. The hematological and biochemical effect of FMD virus on infected and control animals was also determined.

\section{Material and Methods}

\section{Animals}

A total number of forty female buffaloes and cows (6 months -2 years old) were used in the current study. The animals were examined in Dakahlia Governorate from Belqas Center during March and April 2016 . The examined animals were divided into four equal groups, apparently healthy buffaloes and cows $(n=10$, each) and clinically suspected buffaloes and cows $(n=10$, each).

\section{Samples}

Two blood samples each of $5 \mathrm{~mL}$ were collected from the jugular vein of each animal. The first blood sample was taken in clean Wasserman tubes containing dipotassium salts of EDTA for hematological examination. The other sample was collected without anticoagulant in a plain centrifuge test tube, then left to clot and centrifuged at 3000 r.p.m for $20 \mathrm{~min}$ for biochemical analysis.

Samples from clinically suspected animals showing clinical symptoms $(n=20)$ were collected in a transport buffer and stored at $20^{\circ} \mathrm{C}$ until examined. These samples included saliva and vesicular fluid.

\section{RNA extraction and RT-PCR}

Total RNA was extracted from saliva and vesicle fluid using the QIAmp RNA extraction kit (Qiagen, USA) according to the manufacturer's instructions. The extracted RNA was reverse transcribed using the QIAGEN One Step RT-PCR Kit (Qiagen, USA) according to the manufacturer's instructions. To confirm the presence of FMDV serotypy O, 1F:5'- ACC AAC CTC CTT GAT GTG GCT 3'; 1R: 5' GAC ATG TCC TCC TGC ATC TG-3' [10] primer sets amplifying $1301 \mathrm{bp}$ were used. The reaction mixture composed of $1 \mu \mathrm{L}$ of each the forward primer and reverse primer, RNase free water $(100 \mu \mathrm{L})$, 5x QIAGEN one step RT-PCR buffer $(10 \mu \mathrm{L})$, dNTP Mix $(2 \mu \mathrm{L})$, QIAGEN One Step RT-PCR
Enzyme Mix $(2 \mu \mathrm{L})$ and template RNA $(10 \mu \mathrm{L})$ in $50 \mu \mathrm{L}$ reaction volume. Amplification reaction was done under the following conditions; one cycle of $50^{\circ} \mathrm{C}$ for $30 \mathrm{~min}$ for reverse transcriptation, one cycle of $95^{\circ} \mathrm{C}$ for 15 min for pre denaturation followed by 30 cycles of $94^{\circ} \mathrm{C}$ for $1 \mathrm{~min}, 58^{\circ} \mathrm{C}$ for $1 \mathrm{~min}$ and $72{ }^{\circ} \mathrm{C}$ for $1.5 \mathrm{~min}$ for extension, and finally, one cycle of $72^{\circ} \mathrm{C}$ for $10 \mathrm{~min}$ for final extension in Techne thermocycler, UK. The PCR products were confirmed by $1.5 \%$ agarose gelelectrophoresis after ethidium bromide staining and viewing under UV light alongsidea DNA weight markers (Bioneer, Korea).

\section{Hematological examination}

Erythrocytes, total and differential leukocytic counts were performed [11]. The packed cell volume (PCV) was estimated by the microhematocrit centrifuge and hemoglobin $\mathrm{Hb}$ was determined using the cyanmethemoglobin colorimetric method [12]. The values of Mean corpuscular volume $(\mathrm{MCV})$, mean corpuscular hemoglobin $(\mathrm{MCH})$ and mean corpuscular hemoglobin concentration (MCHC) were calculated.

\section{Biochemical examination}

$\begin{array}{ccc}\text { Serum activities } & \text { of } & \text { aspartate } \\ \text { aminotransferase (AST) and alanine }\end{array}$ aminotransferase (ALT) were measured colorimetrically [13]. The serum bilirubin levels (total, direct and indirect) were determined [14]. Serum levels of creatinine, total proteins [15], albumin [16], blood urea nitrogen (BUN) [17], glucose [18] and cortisol [19] were also estimated. Serum protein electrophrosis was accomplished using a polyaccrylamide gel by using kits of cobasintegra company (Roche, Germany) following the manufaturers instructions. Finally, CPK determined using commercial kits from (Specterum company, Egypt) [20].

\section{Statistical analysis}

Statistical analysis was carried out using PASW Statistics (SPSS version 16.0 for Windows). An independent $t$-test was used to compare means from infected and healthy animals. 


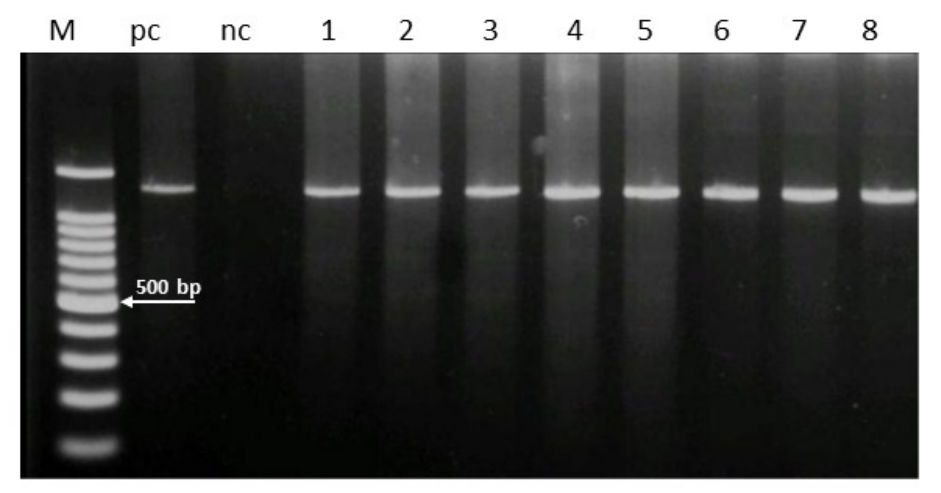

Figure 1: RT-PCR image: Lane-M, 100-bp DNA marker; Lane-PC: positive control (O/EGY/93) Lane-NC: negative control; Lane-1 to 8: FMDV isolates (serotype 0 ) from infected cows and buffaloes 1 to 8 (1301bp).

\section{Results}

\section{PCR Analysis}

Molecular diagnosis of FMDV serotype O revealed that samples collected from all clinically suspected animals were positive by RT- PCR amplification (Figure 1). While, the apparently healthy group were negative by PCR and considered as a control group.

\section{Clinical signs}

Suspectec FMD buffaloes and cows showed fever, inappetence, anorexia, excessive foamy salivation and vesicular eruptions on buccal mucosa (Figure 2).

\section{Hematology}

The total number of RBCs, $\mathrm{Hb}$ and PCV in the FMD infected buffaloes were significantly decreased compared to apparently healthy buffaloes. The $\mathrm{MCH}$ value was significantly increased, with nonsignificant changes in $\mathrm{MCV}$ and MCHC in the FMD group. There were a significant increase in TLC, neutrophil count and a significant decrease in eosinophile and lymphocyte counts, with no significant differences in basophile and monocyte count between the groups (Tables $1,2)$. Moreover, cows infected with FMD virus showed no significant changes in erythrogram compared with normal control. Significant increases in TLC and neutrophiles with significant decreases in eosinophiles and lymphocytes with no significant changes in monocytes when compared with normal control cows (Table 2).
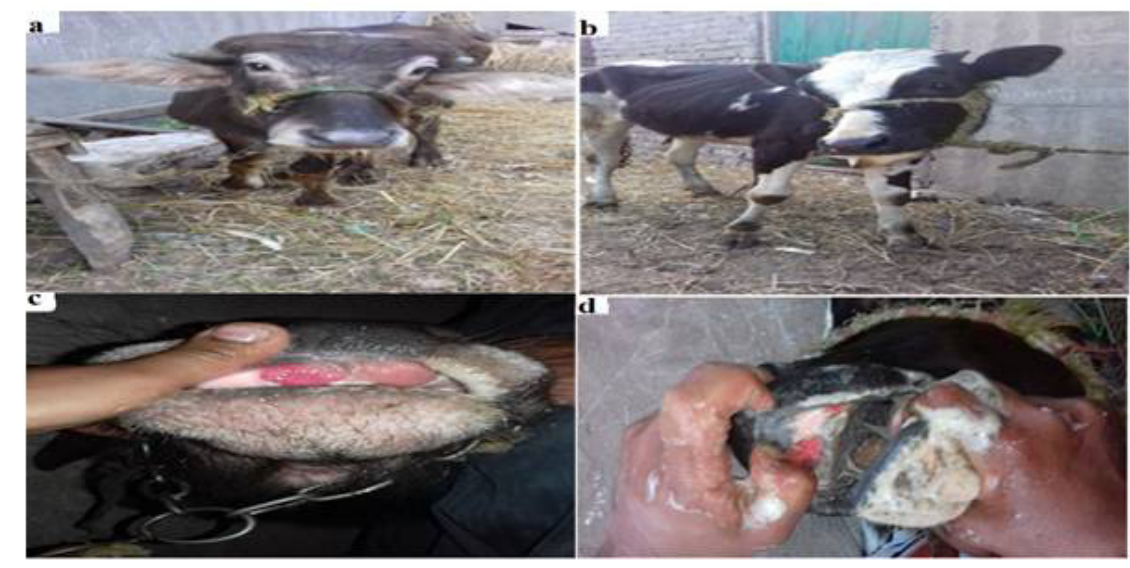

Figure 2: a) Excessive foamy salivation in infected buffalo. b) Excessive foamy salivation in infected cows. C) vesicular eruptions on buccal mucosa of infected buffalo. d) vesicular eruptions on buccal mucosa infected cows. 


\section{Biochemical examination}

The serum levels of total proteins $(\mathrm{P}<$ $0.05)$, albumin $(\mathrm{P}<0.001)$, globulin $(\mathrm{P}<$ $0.01), \alpha 1$ and $\alpha 2$ globulins $(\mathrm{P}<0.01), \beta$ globulin $(\mathrm{P}<0.001)$ and $\delta$ globulin $(\mathrm{P}<0.01)$ were significantly decreased in infected buffaloes, while the serum AST $(\mathrm{P}<0.001)$, CPK $(\mathrm{P}<0.001)$, glucose $(\mathrm{P}<0.01)$ and cortisol $(\mathrm{P}<0.001)$ levels significant increase in buffloes infected with FMD virus $(\mathrm{P}<$ 0.001). No significant changes were recorded in the other biochemical parameters between control and FMD groups (Tables 1 and 2). Cows infected with FMD virus showed a significant decrease in the levels of serum total protein $(\mathrm{P}<0.001)$, albumin $(\mathrm{P}<0.001)$, globulin $(\mathrm{P}<0.01), \alpha-2$ - globulin $(\mathrm{P}<0.05), \beta$ globulin $(\mathrm{P}<0.01)$ and $\delta$ globulin $(\mathrm{P}<0.001)$. The serum AST $(\mathrm{P}<0.01)$, CPK $(\mathrm{P}<0.001)$, glucose $(\mathrm{P}<0.01)$ and cortisol $(\mathrm{P}<0.01)$ were significantly increased, with nonsignificant changes in the other biochemical parameters in cows infected with FMDV compared with the control group (Table 2).

Table 1: Hematological and biochemical parameters (mean \pm SD) in the FMD infected buffaloes compared with the normal control

\begin{tabular}{|c|c|c|}
\hline Parameters & Control buffaloes & Infected buffaloes \\
\hline $\mathrm{RBCs} \times 106 / \mu \mathrm{L}$ & $7.11 \pm 0.12$ & $6.24 \pm 0.08^{* * * *}$ \\
\hline Hemoglobin gm\% & $10.16 \pm 0.17$ & $9.32 \pm 0.10^{* *}$ \\
\hline Packed cell volume \% & $32.00 \pm 0.83$ & $28.00 \pm 0.31^{* *}$ \\
\hline Mean corpuscular volume fl & $44.98 \pm 0.58$ & $44.89 \pm 0.62$ \\
\hline Mean corpuscular hemoglobin pg & $14.40 \pm 0.01$ & $14.94 \pm 0.16^{*}$ \\
\hline Mean corpuscular hemoglobin concentration \% & $32.00 \pm 0.43$ & $33.29 \pm 0.43$ \\
\hline Total leukocytic counts $\times 10^{3} / \mu \mathrm{L}$ & $8.44 \pm 0.16$ & $9.40^{\mathrm{a}} \pm 0.33^{*}$ \\
\hline Neutrophil $\times 10^{3} / \mu \mathrm{L}$ & $3.68 \pm 0.14$ & $5.45 \pm 0.23^{\text {**** }}$ \\
\hline Eosinophil $\times 10^{3} / \mu \mathrm{L}$ & $0.08 \pm 0.003$ & $0.02 \pm 0.01^{*}$ \\
\hline Basophil $\times 10^{3} / \mu \mathrm{L}$ & $0.00 \pm 0.00$ & $0.00 \pm 0.00$ \\
\hline Lymphocyte $\times 10^{3} / \mu \mathrm{L}$ & $4.44 \pm 0.08$ & $3.68 \pm 0.13^{* *}$ \\
\hline Monocyte $\times 10^{3} / \mu \mathrm{L}$ & $0.25 \pm 0.009$ & $0.23 \pm 0.008$ \\
\hline Total protein g/dl & $7.51 \pm 0.40$ & $5.99 \pm 0.066^{* * *}$ \\
\hline Albumin g/dl & $3.064 \pm 0.11$ & $2.82 \pm 0.033^{* * *}$ \\
\hline Total globulin g/dl & $3.87 \pm 0.14$ & $3.17 \pm 0.058^{* *}$ \\
\hline$\alpha-1$-globulin g/dl & $0.44 \pm 0.035$ & $0.29 \pm 0.009^{* * *}$ \\
\hline$\alpha$-2-globulin g/dl & $0.74 \pm 0.036$ & $0.56 \pm 0.029^{* *}$ \\
\hline$\beta$-globulin g/dl & $0.93 \pm 0.031$ & $0.75 \pm 0.019^{* * *}$ \\
\hline$\delta$-globulin g/dl & $1.75 \pm 0.040$ & $1.56 \pm 0.012^{* *}$ \\
\hline Alanine aminotransferase (U/L) & $16.60 \pm 0.93$ & $16.60 \pm 0.68$ \\
\hline Aspartate aminotransferase (U/L) & $71.60 \pm 0.81$ & $89.20 \pm 1.93^{* * *}$ \\
\hline Total Bilirubin mg/dl & $0.46 \pm 0.02$ & $0.46 \pm 0.014$ \\
\hline Direct Bilirubin mg/dl & $0.3 \pm .013$ & $0.28 \pm 0.009$ \\
\hline Indirect Bilirubin mg/dl & $0.166 \pm 0.026$ & $0.18 \pm 0.019$ \\
\hline CPK (U/L) & $223.45 \pm 3.07$ & $262.26 \pm 3.83^{* * *}$ \\
\hline Glucose mg/dl & $42.34 \pm 1.138$ & $50.76 \pm 1.51^{* *}$ \\
\hline Cortisol $\mu \mathrm{g} / \mathrm{dl}$ & $1.188 \pm 0.069$ & $2.33 \pm 0.227^{* * *}$ \\
\hline Creatinine mg/dl & $1.44 \pm 0.083$ & $1.3000 \pm 0.20976$ \\
\hline Urea mg/dl & $23.32 \pm 0.838$ & $23.58 \pm 1.803$ \\
\hline
\end{tabular}

*Significant at $\mathrm{P} \leq 0.05$ **Highly significant at $\mathrm{P} \leq 0.01$ ***Very highly significant at $\mathrm{P} \leq 0.001$. 
Table 2: Hematological and biochemical parameters (mean \pm SD) in the FMD infected cows compared with the normal control

\begin{tabular}{|c|c|c|}
\hline Parameters & Control cows & Infected cows \\
\hline RBCs $\times 106 / \mu \mathrm{L}$ & $5.45 \pm 0.035$ & $5.35 \pm 0.041$ \\
\hline Hemoglobin gm\% & $8.88 \pm 0.185$ & $8.60 \pm 0.141$ \\
\hline Packed cell volume \% & $28.40 \pm 0.93$ & $28.20 \pm 0.66$ \\
\hline Mean corpuscular volume fl & $52.12 \pm 1.77$ & $52.67 \pm 0.92$ \\
\hline Mean corpuscular hemoglobin pg & $16.29 \pm 0.26$ & $16.07 \pm 0.28$ \\
\hline Mean corpuscular hemoglobin concentration $\%$ & $31.43 \pm 1.37$ & $30.55 \pm 0.72$ \\
\hline Total leukocytic counts $\times 10^{3} / \mu \mathrm{L}$ & $8.83 \pm 0.189$ & $10.36 \pm 0.166^{* * *}$ \\
\hline Neutrophil $\times 10^{3} / \mu \mathrm{L}$ & $3.56 \pm 0.109$ & $5.964 \pm 0.112^{* * *}$ \\
\hline Eosinophil $\times 10^{3} / \mu \mathrm{L}$ & $0.092 \pm 0.003$ & $0.032 \pm 0.022^{* *}$ \\
\hline Basophil $\times 10^{3} / \mu \mathrm{L}$ & $0.00 \pm 0.00$ & $0.00 \pm 0.000$ \\
\hline Lymphocyte $\times 10^{3} / \mu \mathrm{L}$ & $4.91 \pm 0.148$ & $4.066 \pm 0.149$ \\
\hline Monocyte $\times 10^{3} / \mu \mathrm{L}$ & $0.27 \pm 0.01$ & $0.26 \pm 0.01$ \\
\hline Total protein g/dl & $5.67 \pm 0.131$ & $4.25 \pm 0.05^{* * *}$ \\
\hline Albumin g/dl & $2.85 \pm 0.09$ & $2.11 \pm 0.02^{* * *}$ \\
\hline Total globulin g/dl & $2.82 \pm 0.13$ & $2.10 \pm 0.016^{* *}$ \\
\hline$\alpha-1$-globulin g/dl & $0.36 \pm 0.05$ & $0.27 \pm 0.02$ \\
\hline$\alpha$-2-globulin g/dl & $0.64 \pm 0.02$ & $0.57 \pm 0.02^{*}$ \\
\hline$\beta$-globulin g/dl & $0.69 \pm 0.03$ & $0.53 \pm 0.02^{* *}$ \\
\hline$\delta$-globulin g/dl & $1.12 \pm 0.05$ & $0.73 \pm 0.02^{* * *}$ \\
\hline Alanine aminotransferase (U/L) & $20.70 \pm 0.56$ & $21.07 \pm 0.77$ \\
\hline Aspartate aminotransferase (U/L) & $54.40 \pm 1.36$ & $65.80 \pm 1.93^{*}$ \\
\hline Total Bilirubin mg/dl & $0.36 \pm .0 .02$ & $0.35 \pm 0.019$ \\
\hline Direct Bilirubin mg/dl & $0.23 \pm 0.01$ & $0.23 \pm 0.01$ \\
\hline Indirect Bilirubin mg/dl & $0.13 \pm 0.02$ & $0.12 \pm 0.02$ \\
\hline CPK (U/L) & $107.12 \pm 1.16$ & $124.47 \pm 1.46^{* * *}$ \\
\hline Glucose $\mathbf{m g} / \mathbf{d l}$ & $60.74 \pm 1.72$ & $69.93 \pm 0.93^{* *}$ \\
\hline Cortisol $\mu \mathrm{g} / \mathrm{dl}$ & $1.88 \pm 0.18$ & $3.90 \pm 0.41^{* *}$ \\
\hline Creatinine mg/dl & $1.21 \pm 0.03$ & $1.23 \pm 0.02$ \\
\hline Urea mg/dl & $28.11 \pm 0.43$ & $28.56 \pm 0.35$ \\
\hline
\end{tabular}

*Significant at $\mathrm{P} \leq 0.05$ **Highly significant at $\mathrm{P} \leq 0.01$ ****Very highly significant at $\mathrm{P} \leq 0.001$.

\section{Discussion}

FMD is one of the most infectious and vital transboundary animal diseases [21]. Clinically infected animals with FMD virus showed fever, anorexia, excessive salivation and vesicular stomatitis. These signs were reported as the characteristic signs of FMD virus [22]. In this study, serotype $\mathrm{O}$ of FMDV was found circulating in buffaloes and cattle. These findings coinside with other reports indicating the predominance of serotype $\mathrm{O}[10,21,22]$. In infected cows there were no significant changes in RBCs, $\mathrm{Hb}, \mathrm{PCV}, \mathrm{MCV}, \mathrm{MCH}$ and $\mathrm{MCHC}$ in comparison with apparently healthy ones [23], this might be due to the absence of hemorrhage and hemolysis in cows with FMD infection [24]. In infected buffaloes, there was a decrease in the level of RBCs than the control group which could be attributed to a 
reduction of the process of erythropoesis [24]. The normocytic normochromic anemia could be resulted from endocrinopathy occurring secondary to viral infection [25] or due to decreased feed intake as a consequence of mouth ulceration. The results of total and differential leukocytic count revealed a significant increase in total leukocytic count with the presence of a highly significant neutrophilia, esinopenia, lymphopenia and no significant change in monocytic count in infected buffaloes and cows. Such increase in the phagocytic cells (neutrophils) could be due to tissue destruction [26]. The lymphopenia may be resulted from the infection of $\mathrm{T}$ and $\mathrm{B}$ cells with Foot and mouth disease virus in short periods of time post infection, corresponding with the peak of viremia and thus causes a transient immunosuppression [27]. Serum biochemical analysis of infected buffaloes and cows showed significant decrease in total proteins, albumin and globulin. The hypoprotenemia and hypoalbuminemia may be a consequence of off food due to oral lesions [28]. It is clear that protein requirements and protein catabolism increases in case of infections or any lesions in the body [29]. The current finding of protein electrophoresis in cows and buffaloes infected with FMDV revealed significant decrease in total globulins and gamma globulins, this may be explained by the increase in the level of cortisol which suppress the activity of the immune system by inhibiting the lymphoid mitosis and reducing the immune cell number and function [30].

There were non significant changes in the serum ALT activity, BUN and Creatinine levels in the present results indicating normal liver and kidney functions revealing that FMDV had no effect on liver and kidney functions. Moreover, a highly significant increase in the activity of AST, CPK, glucose and cortisol hormone was observed in infected buffales and cows. The increased activity of AST may due to the vesicular stomatitis, muscular or cardiac lesions [31]. Higher rectal temperature due to fever in infected animal induces stress condition which might have accelerated the transaminase activity. The serum level of glucose was significantly increased in diseased animals compared to control one, indicating hyperglycaemia [32]. The hyperglycaemia may be due to destruction of beta cells of islets of Langerhans resulting from FMD virus multiplication which leads to defect in insulin production [33]. FMD infected animals revealed elevation in the serum $\mathrm{CPK}$, which indicated myocardial degeneration, that support the high mortality in young animals due to the degenerative effect of FMD on the myocardium [34].

\section{Conclusion}

It could be concluded from the presented study that FMDV serotype $\mathrm{O}$ is circulating in the study area. The virus had more seriously effect on hematological, biochemical parameters and stress marker in buffaloes more than cows.

\section{Conflict of interest}

The authors have no conflict of interest to declare.

\section{References}

[1] Shawky, S.M.; Thabet, N.S.; Orabi, S.H. and Nayel, M.A. (2016): A Comparative Study on the Hemato-Biochemical and Immunological Effects of the Hexavalent FMD Vaccine Alone or in Combination with Trivalent FMD Vaccine in Cattle. JoBiosci Med, 4(1) 16-26.

[2] Barkakati, J.; Sarma, S. and Kalita, D.J. (2015): Effect of foot and mouth disease on haematological and biochemical profile of cattle. JAnim Res, 49(5): 713716

[3] Bachrach, H.L. (1968): Foot-and-mouth disease virus. Annu Rev Microbiol, 22(1):201-44

[4] Yang, P.C.; Chu, R.M.; Chung, W.B. and Sung, H.T. (1998): Epidemiological characteristics and financial costs of the 1997 foot-and-mouth disease epidemic in Taiwan. Vet Rec. 145(25):731-4.

[5] Maddur, M. S.; Kishore, S.; Gopalakrishna, S.; Singh, N.; Suryanarayana, V. V. and Gajendragad, M. R. (2009): Immune Response and Viral Persistence in Indian Buffaloes (Bubalus bubalis) Infected with Foot-and-Mouth Disease Virus Serotype Asia 1. Clin Vaccine Immunol, 16 (12): 1832-1836. 
[6] Belák, S. and Thorén, P. (2001) Molecular diagnosis of animal diseases: some experiences over the past decade. Expert Rev Mol Diagn, 1(4): 434-443

[7] Boom, R.; Sol, C.J.; Salimans, M. M.; Jansen, C.L.; Wertheim-van Dillen, P. M. and van der Noordaa, J. (1990) Rapid and simple method for purification of nucleic acids. J Clin Microbiol, 28(3):495-503

[8] Bustin, S.A. (2000) Absolute quantification of mRNA using real-time reverse transcriptionpolymerase chain reaction assays. J Mol Endocrinol, 25(2): 169-193

[9] Callahan, J.D.; Brown, F.; Osorio, F.A.; Sur, J.H.; Kramer, E.; Long, G.W.; Lubroth, J.; Ellis, S.J.; Shoulars, K.S.; Gaffney, K.L.; Rock, D.L. and Nelson, W.M. (2002) Use of a portable real-time reverse transcriptase-polymerase chain reaction assay for rapid detection of footandmouthdisease virus. J Am Vet Med Asso. 220(11): 1636-1642

[10] Reid, S.M.; Ferris, N.P.; Hutchings ,G.H.; Samuel,A.R. and Knowies, J.L. (2000): Primary diagnosis of foot-and-mouth disease by reverse transcription polymerase chain reaction. $\mathrm{J}$ virol Methods, 89(1): 167-176.

[11] Feldman, B.F.; Zinki, J.G. and Jain, V.C. (2000): Schalm's Veterinary Hematology, $5^{\text {th }}$ Ed., Lippincott Williams and Wilkins, Canda.

[12]Zijlstra, N.C. (1960): Estimation of hemoglobin. Clinica Chimica Acta, 5: 719.

[13] Reitman, S. and Frankel, S. (1957): A colorimetric method for determination of serum AST and ALT. Am J Clin Pathol, 28(1):56-63.

[14] Doumas, B.T.; Bayso, D.D.; Carter, R.J.; Peters, T. and Schaffer, R. (1981): A candidate reference method for determination of serum total protein. I. Development and validation. Clin Chem, 27(10): 1642-1650.

[15] Henry, T.J. (1974): Clinical Chemistry, Principles and Techniques. $2^{\text {nd }}$ Ed., Harper and Row Publishers. New York.
[16] Jendrassik, L. and Grof, P. (1938): Determination of serum bilirubin. Biochem Z, 297:81-82.

[17] Patton, C.J. and Crouch, S.R. (1977): Spectrophotometric and kinetics investigation of the Berthelot reaction for the determination of ammonia. Anal Chem, 49:464-469.

[18] Trinder, P. (1969): Quantitative diagnosis of glucose. Ann Clin Biochem., 6: 2433.

[19] Burtis, C.A. and Ashweed, E.R. (1994):"text book clinical chemistry " $2^{\text {nd }}$ ed. W.B. Saunders Company. Philadelphia, pp 1825-1827.

[20] Grunwaldt, E.G.; Guevara, J.C.; Estevez, O.R.; Vicente, A.; Rousselle, H.; Alcuten, N.; Aguerregaray, D. and Stasi, C.R. (2005): Biochemical and haematological measurements in beef cattle in Mendoza plain rangelands (Argentina). Trop Anim Health Prod, 37(6): 527-540

[21] Geering, W.A. and Lubroth, J. (2002). Food and Agriculture Organization of the United Nations. Emergency Prevention System for Transboundary Animal and Plant Pests and Diseases. Preparation of foot-and-mouth disease contingency plans. Food Agriculture Organism, United Nations Rome

[22] Wongsathapornchai, K.; Salman, M.D.; Edwards, J.R.; Morley, P.S.; Keefe, T.J.; Van Campen, H. and Weber, S. (2008): Assessment of the likelihood of the introduction of foot-and-mouthdisease through importation of live animals into the Malaysia - Thailand- Myanmar peninsula. Am J Vet Res, 69(2): 252260.

[23] Ghanem M.M., and Abdel-Hamid, M.O. (2010): Clinical, haematological and biochemical alterations in heat intolerance (panting) syndrome in Egyptian cattle following natural foot and mouth disease virus (FMD). Trop Anim Health Prod,42(6): 1167-1173.

[24] Barkakati, J.; Sarma, S. and Kalita, D.J. (2015): Effect of foot and mouth disease on haematological and biochemical 
profile of cattle. Indian $\mathrm{J}$ Anim Res, 49(5): 713-716.

[25] Gökçe, G.; Gökçe, H.İ.; Güneş, V.; Erdoğan, H.M. and Çitil, M. (2004): Alterations in some haematological biochemical parameters in cattle suffering from FMD .Turk J Anim Sci, 28(4): 723-727.

[26] Nasr, A.E.M. (2013): Clinicopathological studies on the effect of Foot And Mouth disease In Egyptian Buffaloes. Zag Vet J, 41 (5): 133-141.

[27] Díaz-San Segundo, F.; Salguero, F.J.; de Avila, A.; de Marco, M. M. F.; SánchezMartín, M. A. and Sevilla, N. (2006) : Selective lymphocyte depletion during the early stage of the immune response to Foot-and-Mouth disease virus infection in swine. J Virol; 80(5): 2369-2379.

[28] Kaneko, J.J.; Harvey, J.W. and Bruss, M.L. (1997): Clinical biochemistry of Domestic Animals . 5th ed.Academic press California, USA, PP: 661-668.

[29] Meyer, D.J. and Harvey, J.W. (1998): Veterinary Laboratory Medicine: Interpreting and Diagnosis Saundres. Philadelphia. USA.
[30] Nahed, S.T. (2010): Investigation of serum insulin and cortisol concentrations in Foot and Mouth disease infected cattle in relation to changes in serum biochemical variables and protein electrophoretic fractionation profile. Global Vet, 4(5): 450-455.

[31] Hoffmann, W.E. and Solter, P.F. (2008): Diagnostic enzymology of domestic animals. In Clinical Biochemistry of Domestic Animals. Pp:351-378.

[32] Mohapatra, A.P.K.; Kundu, A.K.; Bisoi, P.C. and Prusty, B.M. (2005): Haematological and biochemical changes in crossbred cattle affected with foot and mouth disease. Indian Vet J, 82(2):141144

[33] Sutmoller, P.; Barteling, S.S.; Olascoaga, R.C. and Sumption, K.J. (2003): Control and eradication of foot-and-mouth disease. Virus Res, 91(1): 101-144

[34] Radostits, O.M.; Gay, C.C.; Hinchcliff, K.W. and Constable, P.D. (2007): Veterinary Medicine: A textbook of the diseases of cattle, horses, sheep, pigs and goats. 10th Ed., Elsevier Health Sciences, Philadelphia, PA, USA. Pp:31. 


\begin{abstract}
الملخص العربي
التوصيف الجزيئي، دراسات الدم والكيمياء الحيوية على فيروس الحمى القلاعية النمط المصلي O في الجاموس والأبقار

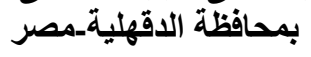

شفاء علي مصطفي المندر اوي و جميلات قطب فرج قطب

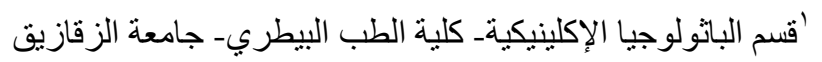

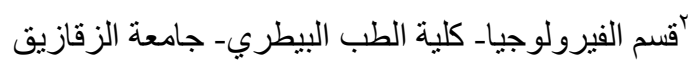

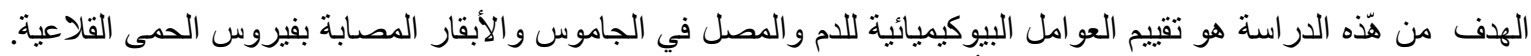

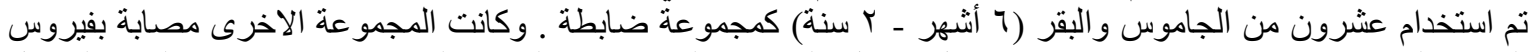

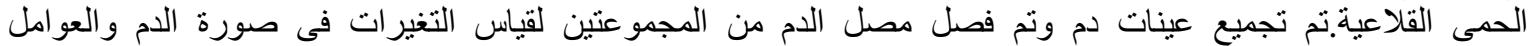

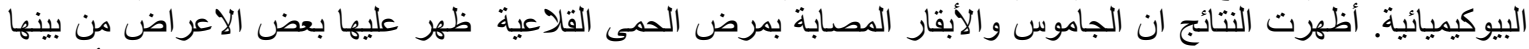

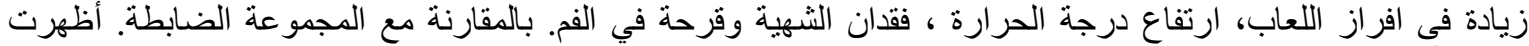

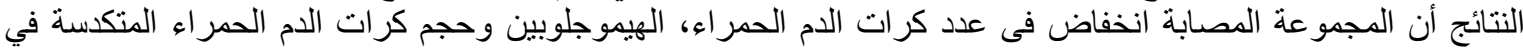

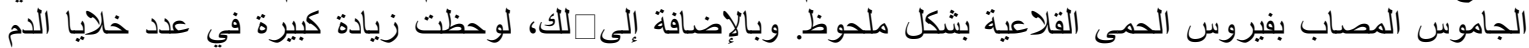

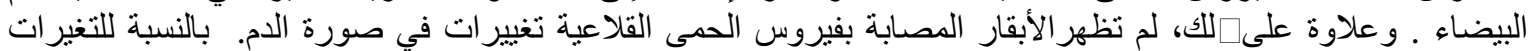

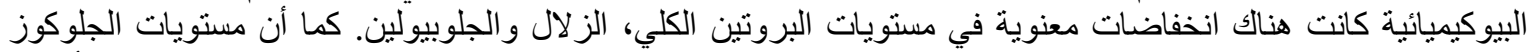

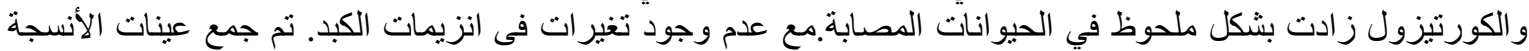

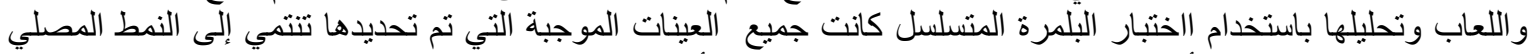
(O) وخلصت الدراسة إلى أن النمط المصلي (O) يصيب كلا من الأبقار و الجاموس.
\end{abstract}

